Folofs.-Although "Jolof" is a word very frequently used in Bathurst, and most of the inhabitants speak that language, yet, as a matter of fact, very few of the genuine race are to be found in it. The habitat of the Jolofs is in the adjoining French colony of Senegal. The Jolofs proper are stated to be a handsome race ; they are proud, and exceedingly vain, claiming for themselves a very ancient descent. The women are inordinately fond of gay apparel and personal adornments of every description. They frequently pierce the ear along the entire edge with $a$ series of holes, so that this feature may be, as far as possible, loaded with ornamentation. The wool is pulled out to its extreme length and plaited into thin strips, which hang from the head, giving a peculiar character to these natives. Of their moral character report speaks very unfavourably, mendacity, deceit, and licentiousness being prominent characteristics of this people. In religion they are fervent Mohammedans; they rarely intermarry with any other race, but are extremely sensitive to any mishap in this direction. The Jolof language is expressive, and has received considerable attention from philologists, more than one grammar having been published. Golberry, who gives a vocabulary of the Jolof language, pertinently comments upon the curious fact that in spite of the contiguity of the Jolofs to the Moors, who adopt the Arabic system of numeration, the former should have persistently adhered to the method of reckoning on one hand only, instead of on both. It is a curious and perplexing circumstance that the Mandingoes, who are an inland people, and probably came into contact with more enlightened races at a later period than the tribes nearer the coast, should be in advance of all the other races in this portion of West Africa in their system of counting. The question whether this method originated with the language, or has been acquired at a later period of their history, must be left for philologists to settle. The Mandingoes, however, have always been great traders, and it is possible that their instincts taught them at an early stage the advantages of a system based on ten fingers instead of five.

Salum Salums. - These are neighbours of the Sereres, and through intermarriage their language is a mixture of Jolof and ierere. In religion they are partly Marabouts and Soninkees. The former frequently take wives from the latter, but no Marabout would give his daughter to a Soninkee unless to a king or a prince, and that reluctantly.

Lowbeys. - This race may be described as the gypsies of North. West Africa. It is almost impossible to obtain any certain information in regard to their history. They wander about from place to place, but have no settled country. There can be no doubt that they are practically the same race as the Foulahs, though for some reason they have become detached from them. Those seen by the Governor were decidely better looking than the average Negro, resembling the Foulahs, though of a darker complexion. They confine themselves almost exclusively to the making of the various wooden utensils in use by natives generally, and the manufacture of canoes. They settle temporarily with any tribe but never intermarry with another race, thus preserving the type of feature which obviously separates them from their human surroundings. In religion most of them are pagans, though a few profess Islamism. They have no laws of their own, but are guided by those of the people with whom they are for the time being located. In case of war happening, they very sensibly remove at once to a district where there is peace. The Foulahs and Toocalores, to whom allusion is made below, are practically the same race. Little need be said of them, as the former are a well-known race, and many travellers have noted their unusual lightness of complexion. Dr. Goulsbury, in his report on the Upper Gambia Expedition, gives a concise history of this people. Their capital is Timbo in the Futa Jallon country. The Toocalores reside principally in the Futa Toro country in Senegal, but from having internixed with other races they are darker in colour. They are a warlike people, and at times are troublesome to our neighbours the French. An appendix to the report contains a vocabulary of common words and expressions used in the Mandingo, Jolof, Serere, Jola, and Foulah languages, all of which are spoken within a comparatively small radius of the Gambia. "No one can fail to be struck with the marked differences in the word forms of the various languages, though Mr. Robert Cust, in his valuable work, "The Modern Languages of Africa,' classes all except the Foulah in one group, which he styles the northern section of the Atlantic sub-group, and which extends from the River Senegal to Cape Mount. It is difficult, however, for any but a trained philologist to detect wherein the relationship lies, or how such radical distinctions could exist and be prescrved in the languages of races living in close proximity to each other. The Jolas especially offer a very curious problem to the ethnologist; it is not probable that they were ever an interior race which has been pushed gradually by stronger neighbours to the sea, and it is somewhat extraordinary that they should have been able hitherto to withstand the power of the conquering Mandingo, and to maintain their individuality. It is true they have always been a savage and intractable people, but in point of numbers their weakness would seem to mark them out as an easy prey to the invaders. This, however, is far from being the case, and there is but little of the Jola country in the hands of strangers."

\section{SEEDLING SUGAR-CANES.}

THE Government of Barbadoes nas issued a valuable Report bearing on seedling sugar-canes. It records the results obtained by Prof. J. B. Harrison ard Mr. J. R. Bovell on the experimental fields at Dodds Reformatory in I889. As the subject is one of great importance to the cane industry, the following extracts may be read with interest. We may note that a paper describing the fruit of the sugar.cane was lately read before the Linnean Society by Mr. D. Morris, and that seedling canes are growing at Kew.

"In our Report for 1888 we briefly alluded, for the purpose of insuring priority, to the fact that we had succeeded in obtaining seedlings of the sugar-cane.

"That the sugar-cane could not produce fertile seeds has been for many years regarded by botanical authorities as a proved and accepted fact, whilst very nany of the older planters here believed that the canes could produce fertile seed.

"Attention here was first strongly directed to this point in I 859 by the Hon. J. W. Parris, who succeeded, at his estate, Highlands, in St. Thomas's parish, in rearing successfully selfsown seedlings.

"Mr. Parris has recently stated to us that he finally succeeded in planting four and a half acres with canes raised from these original seedlings, and that he estimated their yield of sugar at over four hogsheads to the acre. He, however, from certain objectionable characteristics which arose in the canes, finally abandoned their cultivation, and did not again turn his attention to the subject. In order to test the truth of Mr. Parris's discovery of cane seedlings, several persons here attempted to raise them from the cane arrows. This was done successfully by Mr. Carter, of Bridge Cot, and by Mr. I. Wiltshire Clarke, neither of whom, however, appeared to have attached much importance to their results. At another time Mr. T. Clarke, of Cane Field, discovered cane seedlings growing from a fallen cane arrow, but did not succeed in raising them, and Mr. E. S. Sisnett found some cane seeds growing in Christ Church about the year I 86I ; these were allowed to grow amongst canes that were planted in the usual way, but as they were very small and thin when they reached maturity they were destroyed. In this last case the seeds appear to have come from the Bourbon canes. Next we find that the late Mr. W. Drumm paid much attention to this subject and wrote several letters to the Sugar Cane upon it. He, however, stated to us in March I884 that, whilst he had repeatedly obtained cane seed, he had never succeeded in raising canes from it, and that he believed the various instances we have mentioned to be errors of observation.

"At Dodds the cultivation of the different varieties of canes in large numbers and side by side has placed us in a specially favourable condition for examining into this question. In January I 888, Mr. J. B. Pilgrim, one of the overseers at Dodds, reported to us that in the neighbourhood of one of the experimental fields he noticed that certain fine grasses were springing up, and we found at intervals from then to the middle of March similar seedlings. These were found not only on the surface of the field, but also growing in the botiom of a somewhat deep drain which had been recently dug. Much difficulty was experienced in preserving these seedlings, as they were exceedingly sensitive to the effects of exposure to the sun or wind. In June 1888 the seedlings which had survived were transplanted, giving us about 60 plants. Certain of them were dug up with great care, and placed in water until the soil crumbled away from their roots, and were carefully examined for any traces of cane

No. IO8O, vol. 42$]$ 
that might be on the roots. Nothing could be detected, and we were strengthened in an opinion that they were true seedling canes by the very great difference in their mode of growth from that of canes growing from the eyes of canes. A few months later we found that there were several distinct varieties amongst them. In December I 888 we examined them with great care, and grouped them into ten groups according to their most strongly marked characteristics, and found that in many of our groups thus formed the canes graduated from one group into another. Many of these canes exhibited some of the characteristics of certain of our varieties, together with the characteristics of other varieties, but in some cases we could not even form any opinion as to their parentage, as they differed completely from any canes we had ever seen. During the latter stages of their growth these canes were examined by many planters and sugar chemists, all of whom were particularly struck with the amount of variation they exhibited and with the fact that certain of them were entirely different from any canes they had previously seen. The canes, as grouped, were replanted in the usual manner, and are now in course of experimental cultivation. The remaining canes were reaped on March 8 , 1889, and fifty plants yielded 307 pounds of cane tops and 1626 pounds of canes, which gave 6I per cent. of juice of a density of $10^{\circ} \cdot 6$ Beaumé, containing I 629 pounds of sucrose and 0.090 pounds of glucose in the imperial gallon. 'The following are the compositions of the canes, cane-juice, and megass :-

\begin{tabular}{|c|c|c|c|c|c|c|c|c|}
\hline Water & $\cdots$ & & $\cdots$ & $\begin{array}{l}\text { Canes. } \\
68 \cdot 11\end{array}$ & & $\begin{array}{c}\text { Cane-juice. } \\
8 \mathrm{I} \cdot 18\end{array}$ & & $\begin{array}{l}\text { Megass. } \\
48 \cdot 20\end{array}$ \\
\hline Sucrose & $\ldots$ & $\ldots$ & $\ldots$ & $12 \cdot 62$ & $\ldots$ & 15.13 & $\ldots$ & $8.7 \mathrm{C}$ \\
\hline Glucose & $\ldots$ & $\ldots$ & $\ldots$ & 0.69 & $\ldots$ & 0.83 & $\ldots$ & 0.48 \\
\hline Ash $\quad \ldots$ &.$\cdots$ & $\ldots$ & $\ldots$ & 0.47 & $\ldots$ & 0.30 & $\ldots$ & 0.75 \\
\hline Albumino & ids & $\ldots$ & $\ldots$ & 0.33 & $\ldots$ & 0.17 & $\ldots$ & 0.59 \\
\hline Fibre ... & $\ldots$ & $\ldots$ & $\ldots$ & 15.44 & $\ldots$ & - & $\ldots$ & $39 \cdot 60$ \\
\hline Organic $\mathrm{m}$ & natters & & $\ldots$ & $2 \cdot 34$ & $\ldots$ & $2 \cdot 39$ & $\ldots$ & $x \cdot 68$ \\
\hline
\end{tabular}

" In order to definitely settle the question of whether the sugar-cane produced fertile seed, from the middle of December I 888 to that of February I 889 most careful search was made through the fields for growing seedlings and for arrows containing fertile seed. The search for both of these proved successful, but only on the fields in which the varieties were growing and on which, as pointed out by us in our I 888 Report, the conditions for fertilization are most favourable. The seedlings, as found, were transplanted into boxes, but, on account of the unfavourable climatic conditions, great difficulty was experienced in preserving them : on one occasion an accidental exposure to the sun for about three hours destroyed five out of seven contained in the exposed box. One seedling was found attached to a portion of cane arrow which had fallen in a damp and sheltered position. The portions of cane arrows found which apparently contained fertile seed were collected, the apparent seeds carefully separated from the spikelets of the panicles and sown at intervals, commencing on January I2. Ten days after, some of the seeds were seen to be germinating, and certain of them were removed and preserved as microscopic objects. Of the apparent seeds, less than 5 per cent. germinated, and not more than one-fourth of the germinated ones finally survived.

"As the self-sown seedlings and those raised from the seeds by ourselves reached a sufficiently advanced stage of growth (the exceedingly slow growth of the seedlings at an early time is most marked, a point which in certain previous researches may have prevented the attainment of complete proof of the fact that the sugar-cane produces fertile seed, and in which mode of growth the seedlings strikingly differ from the rapid growth of canes from the buds) were, similarly to the seedlings of 1888 , transplanted into the field, and are now in course of experimental cultivation.

"As far as our experience at present shows, the conditions most favourable for the production of fertile seed by the sugarcane are found in the cultivation of varieties side by side and in comparatively large numbers, although from observations recently made, apparently fertilized ovules are to be found from time to time upon arrows of Bourbon canes growing by themselves. To secure the germination of the seeds, it is necessary to sow them soon after the arrow ripens, under similar conditions to those necessary with the seeds of other of the Gramineæ of low germinating power.

NO. IO8O, VOL. 42$]$
"The fertile seeds inclosed in the glumes are long and narrow, being from 3 to 4 millimetres in length and 0.65 to 0.70 millimetres in breadth, and terminate in a beard from 6 to 8 millimetres long."

\section{MUSICAL SCIENCE. ${ }^{1}$}

$\mathrm{THE}$ object of this little pamphlet is one with which musical students are tolerably familiar. The author complains that the science of acoustics, although now well advanced, is unable to explain the actual structure of musical compositions, or to account for their effect on the mind. Many writers bave made the same complaint, and have endeavoured, each according to his own fancy, to "account for" everything by some particular system of his own.

Now, it happens that some quarter of a century ago a person named Helmholtz wrote a great book with the express object of explaining this difficulty. He showed, about as conclusively as anything can be shown, that, although physical science has furnished an intelligible basis on which the musical art is founded, it goes but a very little way in explaining practical musical composition, this being guided chiefly by the æsthetic instincts and the artistic feelings of the best composers, with which physical science can have very little to do.

One would have thought that such a doctrine would be hailed with satisfaction by musicians, as exalting and ennobling the share of art in the generation of high-class music. But, strange to say, it is the musicians who chiefly dispute it, and who would wish to substitute for the heaven-born gift the dry process of scientific deduction.

Our author is of this opinion. He tells us that if by science we are to understand a thorough rational understanding of any subject, musical science has not yet been discovered; it waits still its Columbus, or its Galileo, or its Cuvier.

This may be in a certain sense true, but the science wanted for the purpose is not physical science. We know already pretty well all that physical science can tell us about music; but there is a science much deeper-namely, that which would investigate the general effect produced by mus ic on the mind, as depending on its composition and style. This is the psychology of music, an abstruse branch of æsthetics, and it is this that must tell us, if it can, how music has attained its present power over the feelings and the emotions of mankind. It is only iately that attention has been called to this by competent writers; what is popularly said or sung about it has seldom any serious meaning.

The idea promulgated in this pamphlet is that all the mysteries of the art may be explained on the principles of rhythmnot, as usually understood, having to do with time and measure and accent and so on, but in a more hidden application to the generation of sounds. The system is not completely elaborated, and it is not possible to do more here than give a very general notion of it. The first six chapters treat of rhythms in general; and the author gives a drawing of a macbine for illustrating them. This consists of a series of "Savart" ratchet wheels, which, having different numbers of teeth, can give rise to various rhythmic combinations of their beats. He then deduces "laws" from the consideration of these, of which the following are sume specimens :-

"When we listen to a series of isochronous blows, we perceive them at once in binary rhythm, and we therefore call this perception spontaneous, natural, and instinctive.

"We cannot perceive a series of isochronous blows in ternary rhythm, except with the concurrence of the will; hence we call this perception voluntary."

These are simple fundamental laws; the following are more complicated ones :-

"Whatever is the number of teeth of a wheel, and the velocity at which it revolves, there is always the spontaneons perception of the isochronous series in binary rhythm.

"If, to a series perceived in binary rhythm, we cause another to follow, which has with it any ratio whatever represented by $r$, this will be at once perceived in the same ratio $r$, which proves that the brain is endowed with the faculty of comparison.

"In any association whatever of two series of different rhythms, there is the production of a forced perception which compels the immediate perception of the two rhythms."

1 "Musiconomia: Leggi Fundamentali della Scienza Musicale." By Dr. Primo Crutti, Professor of the History of Music in the Royal Conservatory of Parma. (Parma, 1890.) 